Available online at GSC Online Press Directory

GSC Biological and Pharmaceutical Sciences

e-ISSN: 2581-3250, CODEN (USA): GBPSC2

Journal homepage: https://www.gsconlinepress.com/journals/gscbps

(RESEARCH ARTICLE)

\title{
Qualitative phytochemical and GC-MS analysis of some commonly consumed vegetables
}

\author{
Ezekwe Ahamefula Sunday 1, ${ }^{*}$, Rizwan, A. Ansari ${ }^{2}$, Karimah Mohammed Rabiu ${ }^{3}$ and Ewa Ogbonnaya ${ }^{4}$ \\ ${ }^{1}$ Department of Medical Biochemistry, Rivers State University. Nkpolu Oroworukwo. Port Harcourt Nigeria. \\ ${ }^{2}$ Department of Biochemistry, Yobe State University, Damatru, Nigeria. \\ ${ }^{3}$ Department of Biological Sciences, Yobe State University, Damatru, Nigeria. \\ ${ }^{4}$ Department of Biochemistry, Ahmadu Bello University Zaria, Nigeria.
}

Publication history: Received on 17 September 2020; revised on 01 October 2020; accepted on 06 October 2020

Article DOI: https://doi.org/10.30574/gscbps.2020.12.3.0299

\begin{abstract}
The aim of this research work is to unveil the phytoconstituents of some commonly consumed leafy vegetables which are Talinum triangulare (water leaf), Telfairia occidentalis (fluted pumpkin) and Occimum gratissimum (scent leaf). Freshly harvested vegetables were separately processed into fine powder. $15 \mathrm{~g}$, each of the vegetable powder samples was extracted with methanol. Phytochemical and GC-MS analysis was carried out on the samples using standard procedures. The analysis showed that methanolic leaf extract of fluted pumpkin contains tannins, saponins, phenolics, proteins, anthraquinone and alkaloids with the presence of tannins and saponins being more abundant. However, enquiry into the phytoconstituents of Talinum triangulare leaf indicated that all phytochemicals investigated were reportedly present with saponins and alkaloids being more abundant. For O. gratissimum leaf, tannins, saponins, flavonoids, steroids, phenolics, proteins, anthraquinone and alkaloids were reportedly present. However, like $T$. occidentalis, tannins and saponins were more abundant. GC-MS analysis carried out on the methanolic leaf extract of $T$. occidentalis revealed that nine compounds were present. The five most abundant of the nine compounds include nHexanoic acid (35.23\%), 9, 12, 15-octadecatrienal (12.4\%), imidazolidinedione-5-methyl (10.96\%), L-Proline, 5-oxo-, methyl ester (9.76\%) and 3- [Prop-2-enoyloxy] tetradecane (8.96\%). Meanwhile, 0 . gratissimum showed the presence of only phenol-2-methyl-5-(1-methylethyl) (90.73\%) as the major constituent, while eight (8) compounds were found present in the methanolic leaf extract of T. triangulare (water leaf) and the five more abundant of the eight include pentanoic acid (28.28\%), DL-proline,5-oxo-methyl-buthylester (24.89\%), 3 pyridinecarboxyaldehyde, 0-cetyloxine (E) (21\%), Z-dodecanol (12.68\%) and 4-pyridinol (4.61\%). Findings from this research further support the claim on vegetables as repositories of nutraceuticals.
\end{abstract}

Keywords: Vegetable; Phytochemical; Nutraceutical; Disease

\section{Introduction}

Vegetables are herbaceous plants or a portion of a plant that can be consumed whole or in part, either raw or cooked in order to obtain potentially health aiding compounds called nutraceuticals for effective growth and protection of the body against diseases [1]. The fact that vegetables constitute the major proportion of the diet of the populace in many parts of the world strongly correlates with the increasing public awareness on their health benefits. In fact, research has linked consumption of vegetable rich diets to lowered incidence of cardiovascular diseases, while intake of vegetable deficient diets has been implicated in 31\% of ischaemic heart disease and 11\% of stroke cases [2].

${ }^{*}$ Corresponding author: Ezekwe Ahamefula Sunday

Department of Medical Biochemistry, Rivers State University. Nkpolu Oroworukwo. Port Harcourt Nigeria. 
Owing to urbanization, arable lands have been converted to industrial layouts which translate to a monumental decrease in agricultural productions, while population growth sustains a persistent rise, an imbalance that culminates to food insecurity and consequently, reduced intake of certain nutrients with therapeutic and prophylactic potentials. Therefore, in order to strike a balance between nutrition and health among the populace, the need to x-ray potential sources, notably leafy vegetables for subsequent extraction and identification of inherent phytoconstituents for food bio-fortification purposes becomes an imperative measure towards tackling nutrition and health related urbanization problems.

Talinum triangulare (water leaf)a cosmopolitan weed and a member of the family Portlacaceae, Telfairia occidentalis (fluted pumpkin) a Curcurbitaceous family member and native to the West African high rainfall forest belt and Occimum gratissimum (scent leaf) a perennial aromatic herb belonging to the family Labiatae are the most commonly consumed leafy vegetables by the people of different ethnic background not only in Nigeria but in the entirety of the African continent [3] who have reposed their confidence in these plants for their prophylactic and therapeutic strength against some notable diseases such as measles, anemia and cholera respectively etc [4], a critical factor that stimulates the need for this research which aims at unveiling the phytoconstituents in the aforementioned vegetables to further deepen the understanding of their therapeutic values.

\section{Material and methods}

\subsection{Collection and processing of vegetables}

Fresh leaves of Talinum triangulare (water leaf), Telfairia occidentalis (fluted pumpkin) and Occimum gratissimum (scent leaf) harvested from the university farm were subsequently identified at the herbarium unit of the Department of Forestry, Micheal Okpara University of Agriculture Umudike, Abia State, Nigeria. The leaves were washed with tap water and shade dried at room temperature $\left(28 \pm 2{ }^{\circ} \mathrm{C}\right)$ for seven $(7)$ days. The dried leaves of each of the vegetables were separately ground with the aid of an electric blender and sieved to fine powder. $15 \mathrm{~g}$ each of the vegetable powder samples was extracted with methanol according to the method described by [5]. Extract obtained was subjected to qualitative phytochemical and GC-MS analysis.

\subsection{Qualitative phytochemical analysis}

\subsubsection{Tests for reducing sugar by Fehling's test}

About $0.5 \mathrm{~g}$ of each vegetable samples extract was dissolved in distilled water and filtered. The filtrate was heated with $5 \mathrm{ml}$ of equal volumes of Fehling's solution A and B. Formation of a red precipitate of cuprous oxide was an indication of the presence of reducing sugars [6].

\subsubsection{Test for protein by xanthoproteic test}

Few drops of nitric acid was added to $1 \mathrm{ml}$ of extract of each of the samples by the sides of the test tube and observed for formation of yellow color [7].

\subsubsection{Test for tannins}

About $0.5 \mathrm{~g}$ each of vegetable samples extract was stirred in $10 \mathrm{ml}$ of distilled water and then filtered. Few drops of $1 \%$ ferric chloride solution were added to $2 \mathrm{ml}$ of the filtrate. Appearance of a blue-black, green or blue green precipitate indicates the presence of tannins [8].

\subsubsection{Test for saponins}

$1 \mathrm{~g}$ of each of the samples extract was boiled with $5 \mathrm{ml}$ of distilled water, filtered. To the filtrate, about $3 \mathrm{ml}$ of distilled water was further added and shaken vigorously for about 5 minutes. Frothing which persisted on warming was indicative of the presence of saponins [6].

\subsubsection{Test for alkaloids by Mayer's test}

Exactly $50 \mathrm{mg}$ of extract devoid of solvent is stirred in $2 \mathrm{ml}$ of dilute hydrochloric acid (HCl) and filtered. To the filtrate, few drops of Mayer's reagent were added by the side of the test tube. Formation of white or creamy precipitate indicated the presence of alkaloids [9]. 


\subsubsection{Test for flavonoids by Shinoda's test}

About $0.5 \mathrm{~g}$ of each of the samples extract was dissolved in ethanol, warmed and then filtered. Three pieces of magnesium chips were then introduced into the filtrate. This was followed by the addition of few drops of conc. HCl. Appearance of pink, orange, or red to purple colour showed that flavonoids were present [8].

\subsubsection{Test for terpenoids by Salkowski test}

Exactly $2 \mathrm{ml}$ of chloroform was added to $0.5 \mathrm{~g}$ of the extract. This was followed by the addition of $3 \mathrm{ml}$ conc. $\mathrm{H} 2 \mathrm{SO} 4$ to form a layer. The emergence of a reddish brown colour at the interface was indicative of the presence of terpenoids [9].

\subsubsection{Test for phenols by ferric chloride test}

Few drops of neutral 5\% ferric chloride solution was added to $50 \mathrm{mg}$ each of samples extract dissolved in $5 \mathrm{ml}$ of distilled water. A dark green colour indicated the presence of phenolic compounds [10].

\subsubsection{Test for steroids}

Precisely $5 \mathrm{ml}$ of distilled water was introduced into a test tube holding $0.5 \mathrm{~g}$ of extracts and the mixture shaken vigorously and observed for a stable persistent froth. The resulting froth was mixed with 3 drops of olive oil and shaken vigorously after which it was observed for formation of an emulsion [7].

Tests for cardiac glycosides by Keller Killiani's

Precisely $100 \mathrm{mg}$ each of samples extract was dissolved in $1 \mathrm{ml}$ of glacial acetic acid containing one drop of ferric chloride solution. This was then under layered with $1 \mathrm{ml}$ of concentrated $\mathrm{H}_{2} \mathrm{SO}_{4}$ acid. A brown ring obtained at the interface indicated the presence of de-oxysugar characteristic of cardiac glycosides [7].

\section{Test for free anthraquinones}

About $2 \mathrm{mg}$ each of samples extract was placed in a dry test tube after which $5 \mathrm{ml}$ of chloroform was added and shaken for at least 5 mins. This was filtered and the filtrate was added into an equal volume of $10 \%$ ammonia solution, and was shaken again. The presence of bright pink colouration in the aqueous upper layer was an indicator of the presence of free anthraquinones [11].

\subsection{GC-MS of vegetable samples}

An agilent 7890B Gas Chromatography (GC) system fitted with a $30 \mathrm{~m} \times 250 \mu \mathrm{m} \times 0.25 \mu \mathrm{m}$ Rtx-5MS capillary column coupled to Agilent 5977A Mass Spectrometric (MS) was used at a temperature of $325^{\circ} \mathrm{C}$. Ultra-high purity helium (99.99\%) formed the mobile phase at constant flow rate of $1.0 \mathrm{~cm}^{3} / \mathrm{min}$. The injector, transfer line and ion source temperature were set at $290^{\circ} \mathrm{C}$. The ionizing energy was $70 \mathrm{ev}$. Electron multiplier voltage was obtained from auto tune. The oven temperature was programmed from $60{ }^{\circ} \mathrm{C}$ for $2 \mathrm{mins}$, then $10{ }^{\circ} \mathrm{C} / \mathrm{min}$ to $110{ }^{\circ} \mathrm{C} / \mathrm{min}$ and then $280{ }^{\circ} \mathrm{C}$ at the rate of $5^{\circ} \mathrm{C} / \mathrm{min}$. The sample fractions were diluted with appropriate acetone $(1 / 100 \mathrm{v} / \mathrm{v})$, filtered and $1 \mu \mathrm{L}$ was injected into the inlet. All data were obtained by collecting the total ions currents (TIC). The percentage composition was determined from calibration curve $\left(0-0.9 \mathrm{~g} / \mathrm{cm}^{3}\right)$. The sample and the standard were prepared in like manner. The standard was processed separately prior to being spiked into the sample and signal of the sample was obtained from the difference of the spiked sample and that of the standard. The experiment was repeated more than six times. As a quality control, percentage relative standard (\%RSD) was estimated by comparing coefficient of determination (R2) values of calibration curves using both standard signal and spiked sample signal [12]. 


\section{Results}

Table 1: Qualitative phytochemical constituents of some commonly consumed vegetables

\begin{tabular}{|l|l|l|l|}
\hline & Vegetables & \multicolumn{2}{l|}{} \\
\hline Phytochemicals & Pumpkin Leaf & Water leaf & Scent leaf \\
\hline Tannins & ++ & + & ++ \\
\hline Saponins & ++ & ++ & ++ \\
\hline Flavonoids & + & + & + \\
\hline Steroids & - & + & + \\
\hline Terpenoids & - & + & - \\
\hline Cardiac glycosides & - & + & - \\
\hline Phenolics & + & + & + \\
\hline Proteins & + & + & + \\
\hline Reducing sugars & - & + & - \\
\hline Anthraquinnones & + & + & + \\
\hline Alkaloids & + & ++ & + \\
\hline
\end{tabular}

Table 2: Gas Chromatography-Mass Spectrometric analysis of T. occidentalis (fluted Pumpkin) leaf

\begin{tabular}{|l|l|l|l|l|}
\hline RT & Name of Compound & Molecular Formula & MW & Peak Area \% \\
\hline 6.264 & 2,4-Imidazolidinedione, 5-methyl & $\mathrm{C}_{4} \mathrm{H}_{6} \mathrm{~N}_{2} \mathrm{O}_{2}$ & 114 & 10.96 \\
\hline 7.088 & L-Proline, 5-oxo-, methyl ester & $\mathrm{C}_{6} \mathrm{H}_{9} \mathrm{O}_{3}$ & 143 & 9.76 \\
\hline 9.739 & n-Amylcyclohexane & $\mathrm{C}_{11} \mathrm{H}_{22}$ & 154 & 7.99 \\
\hline 9.840 & Hexahydroindole & $\mathrm{C}_{8} \mathrm{H}_{13} \mathrm{~N}$ & 123 & 4.72 \\
\hline 14.604 & n-Hexadecanoic acid & $\mathrm{C}_{16} \mathrm{H}_{32} \mathrm{O}_{2}$ & 256 & 35.23 \\
\hline 16.899 & 6- Octen-1-ol, 3,7-dimethyl \pm ) & $\mathrm{C}_{10} \mathrm{H}_{20} \mathrm{O}$ & 156 & 4.57 \\
\hline 17.142 & E,E-1,9,17- Docasatriene & $\mathrm{C}_{22} \mathrm{H}_{40}$ & 304 & 5.57 \\
\hline 17.247 & $9,12,15-$ Octadecatrienal & $\mathrm{C}_{18} \mathrm{H}_{30} \mathrm{O}$ & 262 & 12.24 \\
\hline 17.551 & $3-$ Prop-2-enoyloxy]tetradecane & $\mathrm{C}_{17} \mathrm{H}_{32} \mathrm{O}_{2}$ & 268 & 8.96 \\
\hline
\end{tabular}

RT= Retention Time; $\mathbf{M W}=$ molecular weight

Table 3: Gas Chromatography-Mass Spectrometric Analysis of O.gratissimum (Scent) leaf

\begin{tabular}{lllll}
\hline RT & Name of Compound & Molecular Formula & MW & Peak Area \% \\
\hline 5.934 & Phenol, 2-methyl-5-(1-methylethyl) & C10H140 & 150 & 90.73 \\
\hline \multicolumn{2}{r}{ RT= Retention Time; MW= molecular weight }
\end{tabular}


Table 4: Gas Chromatography-Mass Spectrometric Analysis of T. triangulare (water) leaf

\begin{tabular}{|l|l|l|l|l|}
\hline RT & Name of Compound & Molecular Formula & MW & Peak Area \% \\
\hline 7.074 & DL-Proline, 5-oxo-, methyl-, buthyl ester & $\mathrm{C}_{6} \mathrm{H}_{9} \mathrm{NO}_{3}$ & 143 & 24.89 \\
\hline 7.951 & 1-Pentanamine, N-pentyl & $\mathrm{C}_{10} \mathrm{H}_{23} \mathrm{~N}$ & 157 & 2.73 \\
\hline 9.454 & 4- Fluorohistamine & $\mathrm{C}_{5} \mathrm{H}_{8} \mathrm{FN}_{3}$ & 129 & 2.16 \\
\hline 9.833 & 4- Pyridinol & $\mathrm{C}_{5} \mathrm{H}_{5} \mathrm{NO}$ & 95 & 4.61 \\
\hline 11.793 & Adenosine 3',5'- Cyclic monophosphate & $\mathrm{C}_{10} \mathrm{H}_{12} \mathrm{~N}_{5} \mathrm{O}_{6} \mathrm{P}$ & 298 & 3.22 \\
\hline 12.981 & Z-2-Dodecanol & $\mathrm{C}_{12} \mathrm{H}_{24} \mathrm{O}$ & 184 & 12.68 \\
\hline 13.064 & 3- Pyridinecarboxaldehyde, O-acetyloxime, (E) & $\mathrm{C}_{8} \mathrm{H}_{8} \mathrm{~N}_{2} \mathrm{O}_{2}$ & 164 & 21.43 \\
\hline 14.132 & Pentanoic acid, 2-methyl, butyl ester & $\mathrm{C}_{10} \mathrm{H}_{20} \mathrm{O}_{2}$ & 172 & 28.28 \\
\hline \multicolumn{2}{|r|}{ RT= Retention Time; $\mathbf{M W}=$ molecular weight } & & \\
\hline
\end{tabular}

\section{Discussion}

Phytochemicals are biologically active chemical compounds in plants which wield both medicinal and nutritional potentials [13].This is evident by the fact that n-hexadecanoic acid, one of the major compounds in the methanolic leaf extract of T. occidentalis (fluted pumpkin) has been described as a potent antioxidant as well as a dependable anticancer agent [14]. Similarly, 6-octen-1-ol, 3,7dimethyl also in pumpkin leaf has demonstrated antimicrobial activity [15]. Other compounds such as pyridinol a pyridine derivative and Z-2-Dodecanol derived from the methanolic leaf extract of T. triangulare (water leaf) have shown exciting antibacterial activity especially against gram negative bacteria such as E. coli and S. albus [16]. Phytochemicals are known to impact on plant's colour, aroma, flavor and shield plants against both biotic and abiotic stresses ([17]; [18]). Figure 1.0 shows the results obtained from the qualitative phytochemical analysis performed on three commonly consumed vegetables in Nigeria which are Talinum triangulare (water leaf), Telfairia occidentalis (fluted pumpkin) and Occimum gratissimum (scent leaf). The analysis revealed the presence of tannins, saponins, phenolics, proteins, anthraquinones and alkaloids in the methanolic leaf extract of fluted pumpkin with the presence of tannins and saponins being more abundant. This may be attributed to the solubility characteristics of the phytochemicals in the solvent (methanol) used for extraction. These findings are consistent with the work of Ogbonnaya and Uadia [19] which reported similar degree of presence (++) for tannins and saponins in the aqueous root extract of Telfairia occidentalis. However, analysis on the phytochemical constituents of Talinum triangulare leaf revealed that all phytochemicals screened for were reportedly present with saponins and alkaloids being more abundant. These findings are consistent with the work of Abideen et al. [20] which reported more presence of saponins and alkaloids in the ethanolic leaf extract of T. triangulare. In the case of 0 . gratissimum leaf, tannins, saponins, flavonoids, steroids, phenolics, proteins, anthraquinones and alkaloids were reportedly present. However, like the T. occidentalis, tannins and saponins were more abundant. This may be linked to the solubility characteristics of the phytochemicals. These findings are in tandem with the work of Priscillia [21] which reported the presence of tannins and saponins in aqueous leaf extract of 0 . gratissimum. Interpretation on mass spectrum GC-MS was performed with the aid of the National Institute Standard and Technology (NIST) database which has over 62,000 patterns. Spectrum generated on unknown compounds was compared with the spectrum of known compounds deposited in the NIST library. The name, molecular weight and structure of the compounds were determined. GC-MS analysis performed on the methanolic extract of T. occidentalis revealed that nine compounds were present as shown in Table 2.0. The five most abundant of the nine compounds include n-Hexdecanoic acid (35.23\%), 9, 12, 15-octadecatrienal (12.4\%), imidazolidinedione-5-methyl (10.96\%), L-Proline, 5-oxo-methyl ester (9.76\%) and 3- [Prop-2-enoyloxy]tetradecane (8.96\%). Table 3.0, shows the outcome of the GC-MS analysis performed on 0 . gratissimum revealing only the major compound phenol, 2-methyl-5-(1-methylethyl) (90.73\%). For T. triangulare however, eight (8) compounds were reportedly present and the most abundant five include pentanoic acid (28.28\%), DL-proline-5-oxo-methyl-buthylester (24.89\%), 3-pyridinecarboxyaldehyde, O-cetyloxine (E) (21\%), Z-dodecanol (12.68\%) and 4-pyridinol (4.61\%).

\section{Conclusion}

Findings from this research clearly justify the known fact that vegetables are rich in phytochemicals including tannins and saponins known for their characteristic therapeutic and prophylactic potentials. GC-MS analysis performed on the methanolic extract of the aforementioned vegetables further revealed some compounds with known therapeutic values and many candidate compounds for drug development. 


\section{Compliance with ethical standards}

\section{Acknowledgments}

Authors are grateful to the technical staff of the Department of Medical Biochemistry, Rivers State University. Nkpolu Oroworukwo, Port Harcourt Nigeria.

\section{Disclosure of conflict of interest}

Authors wish to state that there is no conflict of interest on this work.

\section{References}

[1] Bellary AN, Sowbhagya H, Rastogi NK. Osmotic dehydration assisted impregnation of curcuminoids in coconut slices. Elsevier. 2011; (105):453-459.

[2] Mullie P and Clary P. Association between cardiovascular disease risk factor knowledge and lifestyle. Food and Nutrition Science. 2011; (2):1048-1053.

[3] Burkill HM. The useful plants of West Tropical Africa. 2nd ed. E-I Kew Royal Botanic Gardens, Kew.1994.

[4] Health Facts NG.[internet]. Health Facts designed by iQube Labs. 2015.

[5] Duke JA, Wain KK. Medicinal plants of the World:Computer index with more than 85,000 Entries. Longman Group Ltd, UK. 1981.

[6] Sofowora A. Medicinal Plants and Traditional Medicinal in Africa. 2nd ed. Sunshine House, Ibadan, Nigeria. 1993.

[7] Trease GE, Evans WC. A text book of pharmacognosy.13th ed. Bailliere Tindall Ltd. London. 1989.

[8] Trease GE, Evans WC. A text book of pharmacognosy. 15th ed. Saunders Publishers London. 2002.

[9] Evans WC, Hartcourt B and Company Asia Pvt. Ltd, Singapore. 1997.

[10] Mace ME. Histochemical localization of phenols in healthy and diseased tomato roots. Phytochemicals. 1963; (16):915-925.

[11] Mooza A, Nora A and Shah AK. GC-MS analysis, determination of total phenolics, flavonoid content and free radical scavenging activities of various crude extracts of Moringa peregrina (Forssk.) Fiori leaves. Asian Pacific Journal of Tropical Biomedicine. 2014;4(12): 964-970.

[12] Hasler CM, Blumberg JB. Phytochemicals: Biochemistry and Physiology. Journal of Nutrition. 1999; (129):756757.

[13] Govindaraj S, Rajangam U. GC-MS analysis of methanolic leaf extracts and stem of Marsilea minuta (Linn.) Journal of Complementary and Alternative Medicine. 2017; 3(1):1-13.

[14] Anis B, Nauceur. Phytochemical composition and antimicrobial activities of essential oil and organic extract from Pelargonium graveolens growing in Tunisia. Lipids in Health and Diseases. 2012; (11):167.

[15] Ataf AA, Adnam S, Zarif G, Nasir R, Amin B, Bhajan L, Ezzat K. A Review on the medicinal importance pyridine derivatives. Journal of Drug Design and Medicinal Chemistry. 2015; 1(1):1-11.

[16] Gibson E, Wardel J, Watts CJ. Fruit and Vegetable Consumption, Nutritional Knowledge and Beliefs in Mothers and Children. Appetite. 1998; (31):205-228.

[17] Ogbonnaya EA, Uadia PO. Phytochemical screening and acute toxicity evaluation of Telfairia occidentalis aqueous extracts on rats. Pakistan Journal Pharmaceutical Sciences.2016; 29(3): 913-917.

[18] Mathai K. Nutrition in the adult years. Nutrition and Diet Therapy. 2000; (271): 274-275.

[19] Abideen AA, Uthman TA, Adeniyi SA, Hidayat AO. Assessment of Proximate Composition and Phytochemical Properties of Bitter Leaf (Vernonia amygdalina) and Water Leaf (Talinum triangulare), United International Journal for Research and Technology. 2020; 1(11):23-26.

[20] Priscilla A. Phytochemical screening and mineral composition of the leaves of Ocimum Gratissimum. International Journal of Applied Science Biotechnology. 2016; 4(2):161 -165. 
GSC Biological and Pharmaceutical Sciences, 2020, 12(02), 208-214

[21] Priscilla A. Phytochemical screening and mineral composition of the leaves of Ocimum Gratissimum. Int J Appl Sci Biotechnol. 2016; 4(2): 161 -165. 